\title{
STUDI MORFOMETRIK UDANG JERBUNG (Fenneropenaeus merguiensis de Man) DARI BEBERAPA POPULASI DI PERAIRAN INDONESIA
}

\author{
Eni Kusrini"), Wartono Hadie"), Alimuddin"*), Komar Sumantadinata"*), dan \\ Achmad Sudradjat") \\ *) Pusat Riset Perikanan Budidaya \\ Jl. Ragunan 20, Pasar Minggu, Jakarta Selatan 12540 \\ E-mail:ennyperikanan@yahoo.com \\ **) Departemen Budidaya Perairan-FPIK, Institut Pertanian Bogor \\ Jl. Lingkar Kampus, Kampus IPB Darmaga, Bogor 16680
}

Naskah diterima: 15 Oktober 2008; Diterima publikasi: 20 Desember 2008

\begin{abstract}
ABSTRAK
Udang jerbung, Fenneropenaeus merguiensis merupakan salah satu jenis udang penaeid indegenous yang memiliki prospek untuk dikembangkan sebagai kandidat budidaya tambak. Penelitian ini bertujuan untuk mengetahui keragaman secara morfologi dan jarak genetik udang jerbung dari populasi alam di Selat Sunda, pantai Cilacap, pantai Bengkulu, Selat Lombok, dan pantai Pontianak. Analisis komponen utama (PCA) digunakan untuk mengetahui keragaman morfologi antar populasi alami udang jerbung. Hasil penelitian menunjukkan adanya perbedaan secara morfologi udang jerbung yang diteliti. Populasi Pontianak memiliki keragaman yang paling tinggi dan Bengkulu paling rendah. Dari analisis kluster diperoleh dua kelompok utama yaitu kluster yang pertama terdiri atas Pontianak-Selat Lombok-Bengkulu dan kluster kedua Selat Sunda-Cilacap. Jarak genetik terjauh dimiliki populasi udang jerbung dari CilacapSelat Lombok dan terdekat Cilacap-Selat Sunda.
\end{abstract}

KATA KUNCl: morfometrik, jarak genetik, keragaman, Fenneropenaeus merguiensis

ABSTRACT: Morphological study of several populations of banana prawn (Fenneropenaeus merguiensis) from Indonesian waters. By: Eni Kusrini, Wartono Hadie, Alimuddin, Komar Sumantadinata, and Achmad Sudradjat

Banana prawn, Fenneropenaeus merguiensis, is one of several prospective local crustaceans for shrimp culture. The objective of this study was to reveal the genetic differences among banana prawn populations from Sunda strait, Cilacap coast, Bengkulu coast, Lombok strait, and Pontianak coast. Principle Component Analysis (PCA) was used to determine genetic differences among the five wild populations. Results of the PCA analysis show that there are morphometrically genetic variations among studied banana prawn populations. Banana prawn from Pontianak has the highest variation of morphology. Results of cluster analysis indicate that there are two main clusters where banana prawns from Pontianak, Lombok Strait, and Bengkulu are categorized as the first cluster while Sunda Strait and Cilacap populations are categorized as the second cluster. The highest value of genetic distance is shown by banana prawn populations from Cilacap and Lombok and the lowest value is Cilacap-Sunda Strait.

KEYWORDS: morphometric, population, genetic distance, Fenneropenaeus merguiensis 


\section{PENDAHULUAN}

Udang jerbung atau banana prawn atau white prawn (Fenneropenaeus merguiensis De Man 1888) merupakan udang yang mempunyai nilai ekonomis tinggi, terbukti di beberapa restoran sea food disajikan dengan harga yang cukup mahal. Sampai saat ini produksinya masih bergantung penangkapan dari alam. Ukuran udang jerbung dapat mencapai sebesar udang windu dengan pertumbuhan yang lebih cepat. Udang jerbung ini merupakan udang yang banyak digemari di berbagai negara terutama Australia dan Asia Tenggara. Dalam rangka diversifikasi usaha budidaya krustase, udang jerbung dapat dijadikan salah satu alternatif untuk dikembangkan dan sekaligus diharapkan dapat menjadi andalan komoditas lokal budidaya terutama pada saat udang windu mengalami kendala dalam budidaya. Menanggapi maraknya impor induk udang putih pada beberapa tahun belakangan ini, maka pengembangan teknologi perbenihan dan perbesaran dari berbagai jenis udang lokal yang bernilai ekonomis perlu dilakukan. Beberapa jenis udang lokal seperti Fenneropenaeus indicus, F. merguiensis, dan Penaeus semisulcatus merupakan komoditas yang memiliki peluang untuk dikembangkan di tambak. Secara alami udang jerbung tersebar di perairan di Indonesia. Berdasarkan kajian pengelolaan produksi udang jerbung yang sudah dilakukan sebelumnya, induk udang jerbung dapat dijumpai di Bengkulu, Selat Sunda, Cilacap, Selat Lombok, dan Pontianak.

Upaya yang dapat dilakukan salah satunya adalah pembenihan udang jerbung yang diawali dengan kajian potensi induk dalam mendukung kegiatan domestikasinya. Salah satu aspek yang mempunyai peranan penting dalam domestikasi adalah penyediaan induk yang berkualitas baik untuk budidaya. Langkah awal yang perlu dilakukan adalah mengkarakterisasi secara genetik stok udang jerbung. Pengumpulan informasi mengenai data dasar genetik dari suatu spesies merupakan syarat awal yang diperlukan untuk menentukan variasi genetik atau kekerabatan yang dimiliki.

Pengukuran variasi genetik udang dapat dilakukan berdasarkan karakter fenotipenya (morfometrik, meristik, dan trus morfometrik) dan karakter genotipenya (Isozyme, DNA, dan sekuensing). Pendekatan dengan ukuran komersial (panjang dan bobot) dan karakter meristik dapat digunakan untuk membedakan strain, jenis kelamin, stok, spesies hibrida, atau populasi telah dipakai untuk beberapa jenis ikan dan udang. Pengukuran secara morfometrik merupakan suatu teknik yang lebih baik untuk membedakan bentuk tubuh pada populasi. Pengukuran keragaman genetik berdasarkan karakter fenotipe dengan metode morfometrik lebih mudah dilakukan dengan biaya yang jauh lebih murah dibandingkan dengan pengukuran berdasarkan karakter genotipenya. Morfometrik dapat dilakukan dengan tujuan antara lain untuk membedakan strain/spesies/populasi menentukan jarak genetik dan mencari indikator morfologi untuk tujuan seleksi. Kajian morfometrik pada udang windu telah dilakukan dengan tujuan untuk mencari ciri-ciri morfologi yang dapat dijadikan indikator pendugaan berat daging udang hidup dalam seleksi induk. Karakter morfologi seperti panjang karapas, panjang total tubuh, dan tinggi ruas tubuh VI udang windu memiliki nilai korelasi yang tinggi $(r>0,91)$ dengan bobot daging udang (Sugama et al., 1992). Penelitian ini bertujuan untuk mengetahui variasi secara morfologi dan jarak genetik udang jerbung dari populasi alam di Selat Sunda, Cilacap, Bengkulu, Selat Lombok, dan Pontianak.

\section{BAHAN DAN METODE}

\section{Lokasi Pengambilan Sampel}

Pengambilan sampel udang dilakukan pada lima lokasi yaitu lepas pantai Bengkulu; Selat Sunda, lepas pantai Cilacap, Pontianak, dan Selat Lombok (Gambar 1). Pengambilan sampel pada masing-masing lokasi sebanyak 50 ekor. Pengambilan sampel dengan bantuan nelayan setempat menggunakan trammel net. Selanjutnya dari lokasi pengambilan, sampel diawetkan dalam larutan alkohol $70 \%$ sebelum dilakukan analisis lebih lanjut.

\section{Pengukuran Morfometrik}

Pengukuran morfologi menggunakan kaliper dengan ketelitian $0,01 \mathrm{~mm}$; sementara untuk bobot menggunakan timbangan O-Hous dengan ketelitian 0,01 g. Pengukuran morfometrik merupakan modifikasi teknik pengukuran yang dilakukan oleh Dall (1957) dan Lester (1983). Pengukuran morfometrik meliputi panjang karapas parsial (PKP), kedalaman karapas (DKP), lebar karapas (LKP), panjang ruas pertama (PRP), panjang ruas kedua (PRD), panjang ruas ketiga (PRT), panjang ruas keempat (PRE), panjang ruas kelima (PRL), 


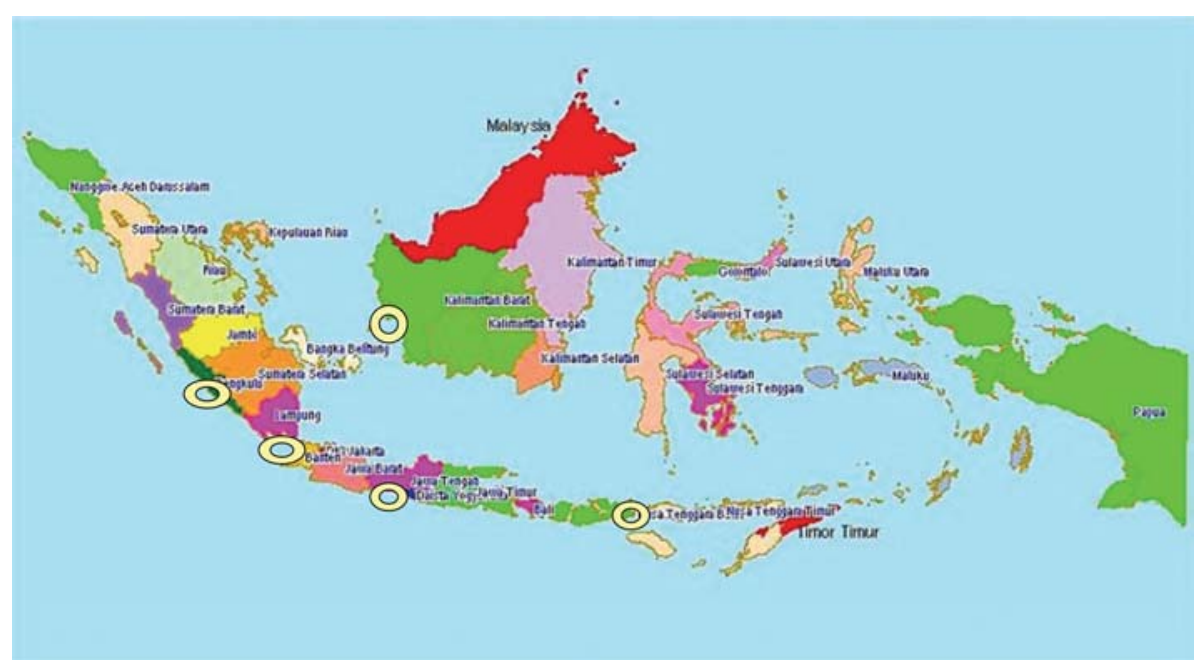

Gambar 1. Lokasi pengambilan sampel udang jerbung, F. merguiensis di Selat Sunda, Cilacap, Bengkulu, Selat Lombok, dan Pontianak

Figure 1. Sampling locations of banana prawn, F. merguiensis (Sunda Strait, Cilacap, Bengkulu, Lombok Strait, and Pontianak)

panjang ruas keenam (PRN), panjang total (PTO), panjang standar (PBD), panjang rostrum (RST), lingkar abdomen anterior (LAA), lingkar abdomen posterior (LAP), kedalaman ruas keenam (DRN), panjang prosertema (PST), exopod (EXP), endopod (END), telson (TLS), bobot total (BTO), dan bobot tanpa kepala (BTK) (Lester, 1983).

\section{Analisis Data}

Analisis diskriminan digunakan untuk melihat perbedaan yang signifikan antar kelompok yang ditentukan oleh karakter morfologi yang diamati. Hasil pengukuran direlatifkan dengan panjang standar untuk menghindari keragaman ukuran dan kemungkinan umur yang berbeda. Selanjutnya akan dikelompokkan karakter morfologi yang paling mencirikan perbedaan tersebut. Adanya pengaruh interaksi sesama karakter yang diukur mengakibatkan penyusutan karakterkarakter tersebut. Komponen ini juga digunakan untuk melihat pengaruh yang paling kuat terhadap pembentukan populasi. Analisis ini menggunakan program SAS 1997 dengan prosedur PROC.PRINCOM dan program SPSS versi 15 yang berdasarkan Analisis Komponen Utama (Principal Component Analysis).

Analisis komponen utama merupakan metode statistik deskriptif yang bertujuan untuk menginterpretasikan sebagian besar informasi yang terdapat dalam suatu matriks data ke dalam bentuk grafik dan untuk mendapatkan peta penyebaran populasi serta nilai kesamaan di dalam maupun di luar kelompok. Hasil yang diperoleh ditampilkan dalam bentuk gambar dendrogram.

\section{HASIL DAN BAHASAN}

Hasil analisis penyebaran karakter morfologi memperlihatkan bahwa karakter morfologi udang dari Selat Sunda dan Cilacap mengumpul dan saling bersinggungan dengan populasi lainnya pada daerah nol garis axis $X$ dan Y. Populasi Bengkulu sedikit bersinggungan dengan populasi Pontianak, sedangkan populasi Selat Lombok tidak bersinggungan dengan populasi Bengkulu. Group centroids dari kelima populasi tersebut berada di area sekitar garis nol dari axis $X$ dan Y (Gambar 2).

Penyebaran karakter udang jerbung pada Gambar 2 menunjukkan bahwa populasi Bengkulu terpisah dengan populasi Selat Lombok. Populasi yang paling luas penyebaran karakter morfologinya adalah Pontianak disusul Selat Lombok, sedangkan populasi Bengkulu, Selat Sunda, dan Cilacap. Hal tersebut sesuai dengan sharing component yang dimilikinya, di mana Pontianak mempunyai keragaman antar populasi terbesar. Menurut Hadie (1997), penyebaran udang biasanya dibagi ke dalam 


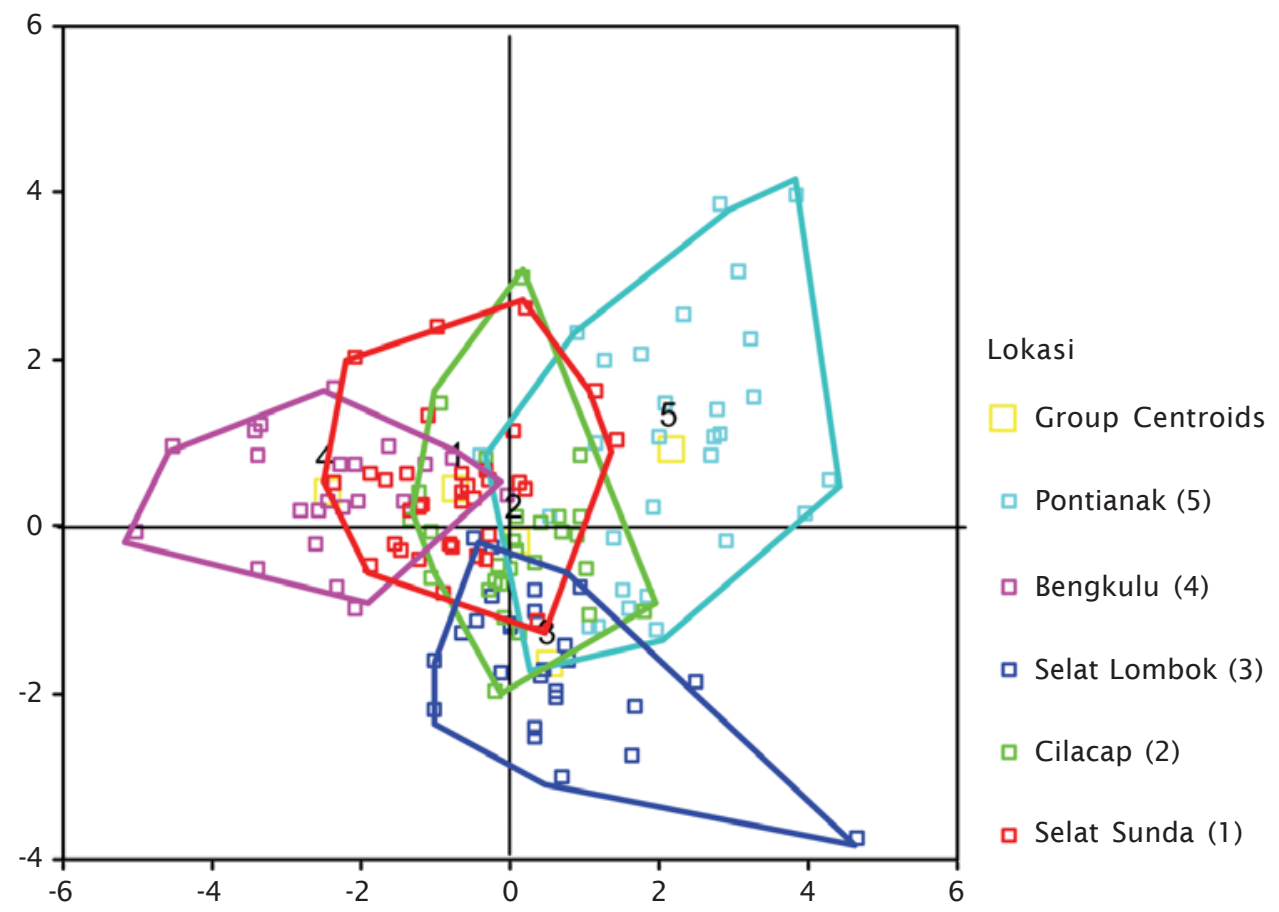

Gambar 2. Penyebaran karakter morfologi udang jerbung (F. merguiensis) dari Selat Sunda, Cilacap, Bengkulu, Selat Lombok, dan Pontianak

Figure 2. Character distribution of banana prawn (F. merguiensis) from Sunda Strait, Cilacap, Bengkulu, Lombok Strait, and Pontianak

beberapa populasi dan dengan berjalannya waktu, populasi jadi terpecah oleh beberapa faktor geografi ke dalam populasi yang terisolasi dan setiap populasi mungkin membentuk karakter yang berbeda, yang akhirnya dapat membedakan populasi satu dengan yang lainnya. Penelitian dengan pengamatan karakter morfologi seperti morfometrik udang jerbung dapat digunakan sebagai pembeda. Menurut Suparyanto et al. (1999), kedekatan kelompok ditunjukkan dengan singgungan antar sampel. Pada gambar penyebaran tersebut populasi Cilacap dan Selat Sunda dekat dengan semua populasi. Hubungan kedekatan populasi Pontianak dan Bengkulu lebih kecil dibandingkan Bengkulu-Selat Sunda-Cilacap. Sementara itu untuk populasi Bengkulu dan Selat Lombok tidak bersinggungan, sehingga dikatakan kedua populasi tersebut jauh hubungan keeratannya. Dengan demikian keberadaan populasi Selat Sunda dan Cilacap menyatukan populasi Bengkulu dan Selat Lombok tersebut.
Keeratan semua karakter morfologi antar populasi yang diteliti akan lebih nyata dengan menggunakan sharing component morfometrik antar daerah sampel. Pendugaan sharing component atau nilai kesamaan (Index of similarity) antar populasi dilakukan dengan menggunakan hasil analisis diskriminan berdasarkan kesamaan ukuran tubuh tertentu (Tabel 1).

Keragaman internal pada populasi Selat Sunda adalah 67,65\%; sharing dengan populasi Pontianak 20,50\% dan Cilacap $11,76 \%$. Keragaman internal populasi Pontianak 57,14\% sharing dengan Selat Sunda 21,43\%; dengan Selat Lombok 14,29\%; dengan Bengkulu dan Cilacap 3,57\%. Populasi Selat Lombok memiliki keragaman internal 75,00\%; sedangkan bentuk 7,14\% dimiliki oleh populasi Selat Sunda dan Cilacap; dan 10,71 dimiliki oleh Pontianak. Demikian juga dengan populasi Bengkulu dengan keragaman internal $86,36 \%$; sharing dengan populasi Selat Sunda 9,09\%; dan 4,55\% dimiliki oleh populasi Cilacap. Sedangkan populasi Cilacap memiliki keragaman internal 
Tabel 1. Percampuran fenotipe dalam dan antar populasi (\%) udang jerbung, F. merguiensis Table 1. Phenotype mixing inter and intra populations (\%) of banana prawn, F. merguiensis

\begin{tabular}{lcccccc}
\hline \multicolumn{1}{c}{$\begin{array}{c}\text { Lokasi } \\
\text { Location }\end{array}$} & $\begin{array}{c}\text { Selat } \\
\text { (Strait) } \\
\text { Sunda }\end{array}$ & Pontianak & $\begin{array}{c}\text { Selat } \\
\text { (Strait) } \\
\text { Lombok }\end{array}$ & Bengkulu & Cilacap & $\begin{array}{c}\text { Total } \\
\text { (\%) }\end{array}$ \\
\hline Selat (Strait) Sunda & 67.65 & 20.59 & 0.00 & 0.00 & 11.76 & 100 \\
Pontianak & 21.43 & 57.14 & 14.29 & 3.57 & 3.57 & 100 \\
Selat (Strait) Lombok & 7.14 & 10.71 & 75.00 & 0.00 & 7.14 & 100 \\
Bengkulu & 9.09 & 0.00 & 0.00 & 86.36 & 4.55 & 100 \\
Cilacap & 3.45 & 6.90 & 17.24 & 0.00 & 72.41 & 100 \\
\hline
\end{tabular}

sebesar $72,41 \%$ dan membagi keragaman dengan populasi Selat Lombok sebesar $17,24 \%$ diikuti Pontianak 6,90\%; dan Selat Sunda $3,45 \%$.

Kesamaan morfologi seperti yang disajikan pada Tabel 1 menunjukkan adanya percampuran (sharing component) yang terukur antara populasi satu dengan yang lainnya. Persamaan ukuran variabel merupakan gejala percampuran antar masing-masing daerah melalui percampuran gen di masa lalu. Nilai kesamaan ukuran tubuh memberikan penjelasan adanya komponen yang merupakan sifat yang dipertahankan atau dibagikan sewaktu terjadi aliran gen (gene flow). Kesamaan ukuran tubuh dalam kelompok yang paling besar dalam populasi adalah pada populasi Bengkulu (86,36\%). Dengan demikian populasi Bengkulu keragaman internalnya tinggi tetapi sedikit dimiliki oleh populasi lainnya. Populasi Pontianak mempunyai nilai sharing component internal kecil dibandingkan populasi lainnya, dengan kata lain populasi internal Pontianak lebih beragam. Dengan demikian, populasi Pontianak bisa dijadikan sebagai sumber induk dalam program seleksi. Pengelompokan komponen tersebut masih terbatas pada sifat yang diamati, oleh karena itu semakin banyak sifat yang diamati semakin memperoleh gambaran yang lebih bagus. Dengan demikian perlu melengkapi dengan karakter lain yang lebih banyak untuk mendukung kesempurnaan posisi masingmasing populasi di dalam persilangannya. Hasil penelitian terhadap udang galah dari tiga populasi alam didapatkan nilai percampuran fenotipe dalam populasi berkisar $68,33 \%-$ $90,00 \%$ sedang antar populasi $5,00 \%-26,67 \%$ (Hadie et al., 2002). Nilai percampuran fenotipe udang windu dalam populasi $40,9 \%-82,2 \%$ dan antar populasi $0,0 \%-27,4 \%$ (Sulaeman et al., 2002 dalam Parenrengi et al., 2007). Sedangkan pada udang pama (Penaeus semisulcatus) nilai percampuran fenotipe dalam populasi berkisar $67,8 \%-93,1 \%$ dan antar populasi 0,0\%-30,5\% (Parenrengi et al., 2007).

Tabel 2. Nilai matrik jarak genetik antar populasi udang jerbung $F$. merguiensis dari Selat Sunda, Cilacap, Bengkulu, Selat Lombok, dan Pontianak

Table 2. Matrix value of genetic distance among banana prawn populations ( $\boldsymbol{F}$. merguiensis) from Sunda Strait, Cilacap, Bengkulu, Lombok Strait, and Pontianak

\begin{tabular}{lccccc}
\hline \multicolumn{1}{c}{$\begin{array}{c}\text { Populasi } \\
\text { Population }\end{array}$} & $\begin{array}{c}\text { Selat } \\
\text { (Strait) } \\
\text { Sunda }\end{array}$ & Pontianak & $\begin{array}{c}\text { Selat } \\
\text { (Strait) } \\
\text { Lombok }\end{array}$ & Bengkulu Cilacap \\
\hline Selat (Strait) Sunda & 0 & & & & \\
Pontianak & 14.57902 & 0 & & & \\
Selat (Strait) Lombok & 17.99525 & 6.76915 & 0 & & \\
Bengkulu & 13.61027 & 10.27115 & 12.21179 & 0 & \\
Cilacap & 5.33364 & 23.76638 & 32.46603 & 20.79215 & 0 \\
\hline
\end{tabular}


Hasil analisis PCA karakter morfologi udang jerbung dengan pendekatan mahalonobis diperoleh nilai matrik jarak genetik (Tabel 2). Kekerabatan terjauh adalah populasi Cilacap dengan Selat Lombok yaitu 32,46603; diikuti dengan populasi Cilacap dengan Pontianak sebesar 23,76638; Cilacap dengan Bengkulu 20,79215; Selat Lombok dengan Selat Sunda 17,99525; Pontianak dengan Selat Sunda 14,57902; Bengkulu dengan Selat Sunda 13,61027; Bengkulu dengan Selat Lombok 12,21179; Bengkulu dengan Pontianak 10,27115; Selat Lombok dengan Pontianak 6,76915; sedangkan yang terdekat adalah Cilacap dengan Selat Sunda yaitu 5,33364.

Matriks jarak genetik antar populasi dalam Tabel 2 merupakan dasar pengelompokan dalam penggambaran dendrogramnya. Nilai jarak genetik terjauh dimiliki populasi CilacapSelat Lombok, dan terkecil populasi CilacapSelat Sunda. Nilai jarak genetik dapat digunakan sebagai acuan dalam persilangan antar populasi. Jika perkawinan dilakukan yang hubungan kekerabatannya jauh diduga akan dapat meningkatkan keragaan secara nyata dibandingkan dengan yang mempunyai hubungan kekerabatan dekat. Hal tersebut dikarenakan heterosisnya hanya berasal dari kelompoknya saja, sedangkan untuk kekerabatan yang jauh dapat diperoleh keragaman dari keduanya (Suparyanto et al., 1999). Implikasi dari nilai tersebut, jika persilangan dilakukan antara populasi
Pontianak X Cilacap atau Cilacap X Lombok atau Cilacap $X$ Bengkulu, diduga dapat meningkatkan keragaan secara nyata dibanding dengan Cilacap X Selat Sunda atau Selat Lombok X Pontianak.

Kekerabatan kelima populasi alam udang jerbung tersebut digambarkan dalam dua kluster utama. Udang jerbung Selat Sunda dan Cilacap menjadi satu kelompok, sedang kelompok lainnya udang jerbung kelompok Pontianak, Selat Lombok, dan Bengkulu (Gambar 3).

Dendrogram hasil pengamatan morfometrik antar populasi diperoleh 2 kelompok (cluster) utama yaitu kelompok Pontianak-Selat LombokBengkulu dan kelompok Cilacap-Selat Sunda. Terjadinya pengelompokan ini kemungkinan disebabkan oleh kedekatan lokasi geografi. Di mana fenotipe suatu individu merupakan ekspresi dari genotipe dan lingkungan. Dengan lokasi geografi yang sama diduga kondisi kualitas air juga relatif sama. Berdasarkan Gambar 3 tersebut, masing-masing populasi mempunyai karakter dan ukuran tubuh yang hampir sama. Sesuai dengan penelitian yang dilakukan oleh Hadie et al. (2002) terhadap udang galah beberapa bagian tubuh yang karena stres lingkungan dapat mempengaruhi perkembangannya. Dengan demikian dapat dikatakan bahwa faktor lingkungan dapat mempengaruhi laju pertumbuhan organ tertentu.

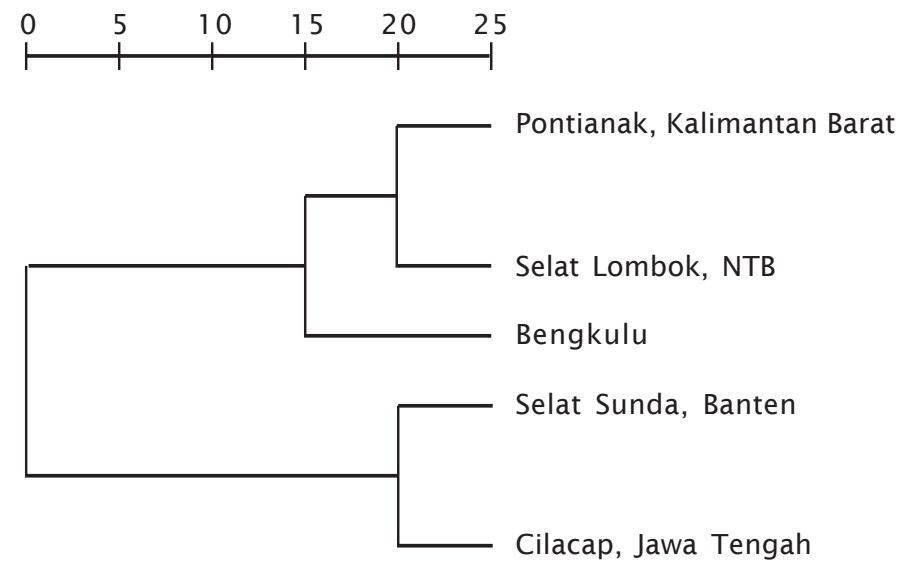

Gambar 3. Dendrogram jarak genetik udang jerbung (F. merguiensis) dari Selat Sunda, Cilacap, Bengkulu, Pontianak, dan Selat Lombok

Figure 3. Dendrogram of genetic distance of banana prawn populations (F. merguiensis) from Sunda Strait, Cilacap, Bengkulu, Lombok Strait, and Pontianak 


\section{KESIMPULAN}

Morfologi yang terekspresi dari perbedaan karakter ukuran tubuh, membentuk 2 kelompok utama yaitu Pontianak-Selat Lombok-Bengkulu dan Cilacap-Selat Sunda, sehingga didapatkan perbedaan morfologi antar populasi udang jerbung yang diambil dari 5 habitat asli. Nilai percampuran di dalam masing-masing populasi udang jerbung adalah $57,14 \%-86,36 \%$. Jarak genetik yang didapatkan memperlihatkan kekerabatan terdekat adalah udang yang berasal dari populasi Selat Sunda dan Cilacap $(5,33364)$ dan terjauh antara Cilacap dan Selat Lombok $(32,466603)$.

\section{UCAPAN TERIMA KASIH}

Riset ini dibiayai oleh DIPA Kegiatan Riset Analisis kebijakan pengembangan perikanan budidaya, Pusat Riset Perikanan Budidaya tahun anggaran 2007.

\section{DAFTAR ACUAN}

Dall, W. 1957. The revision of the Australia species of Penaeinae (Crustacea decapoda: Penaeidae). Aust. J. Mar. Freshwater Res., 8: 136-231.

Hadie, W. 1997. Studi Morfometrik dan Keragaman Genetika pada Populasi Ikan Lele (Clarias batrachus) di Sungai Musi dan Bengawan Solo. Tesis. Program Studi Biologi, Universitas Indonesia, $34 \mathrm{hlm}$.
Hadie, W., K. Sumantadinata, O. Carman, dan L.E. Hadie. 2002. Pendugaan jarak genetik populasi udang galah (Macrobrachium rosenbergii) dari Sungai Musi, Sungai Kapuas, dan Sungai Citanduy dengan Truss morphometric untuk mendukung program pemuliaan. J. Pen. Perik. Indonesia, 8(2): 17.

Lester, L.J. 1983. Developing selective breeding program for penaeid shrimp mariculture. Aquaculture, 33: 41-50.

Parenrengi, A., Sulaeman, W. Hadie, dan A. Tenriulo. 2007. Keragaman morfologi udang pama (Penaeus semisulcatus) dari perairan Sulawesi Selatan dan Sulawesi Tenggara. J. Ris. Akuakultur, 2(1): 27-32.

Sugama, K., Tridjoko, Haryanti, and A. Khalik. 1992. Study on morphometric variability of broodstock for genetic improvement in tiger prawn, Penaeus monodon, J. Pen. Budidaya Pantai, 8(3): 1-8.

Suparyanto, A., T. Purwadaria, dan Subandriyo. 1999. Pendugaan jarak genetik dan faktor peubah pembeda bangsa dan kelompok domba di Indonesia melalui pendekatan analisis morfologi. J. IImu Ternak dan Veteriner, 4: 80-87.

Tave, D. 1995. Selective breeding programme for medium-sized fish farms. FAO Fish. Tech. Paper. No. 352. Rome, Italy, 122 pp. 